\title{
Implementation of Lesson Study Learning Community (LSLC) on Learning Science of Biology in State Junior High School
}

\author{
Herliani $^{1}{ }^{\text {Masitah }}{ }^{2}$ \\ Department of Biology Education, Faculty of Teacher Training and Education, Mulawarman University, Indonesia \\ ellieherliani@gmail.com, sitaeend@yahoo.co.id
}

\begin{abstract}
Development of learning patterns Curriculum 2013, formulate curriculum based learning process that prioritizes personal experience and guide students to find out, not discovery (discovery learning). Through Lesson Study Learning Community (LSLC) it is possible to interact with each other listening, mutual learning, filling each other, and thus providing an experience for improvement of learning. Associated with the implementation of Lesson Study Learning Community (LSLC) has the potential to be a means of biology science learning process. In this case has been done research implementation of lesson study learning community (LSLC) on learning biology science junior high school in Samarinda. The purpose of this research is to know the quality of biology science learning and student learning activities. The data obtained were analyzed by using descriptive analysis with observation method in open class activity. The sample of the research is Student of State Junior High School 2 class VII-I, amounting to 31 people, Lesson Study Learning Community activity to improve the quality of biology science learning and student learning activities.
\end{abstract}

Keywords-Lesson Study Learning Community (LSLC); junior high school; biology science learning

\section{INTRODUCTION}

One way to improve the quality of learning is to conduct a collaborative and sustainable learning assessment based on the principles of collegiality, and build a learning community. This method is known as Lesson Study learning community (LSLC).

Lesson Study is a system of activities and philosophy derived from Japanese (from the word: jugyokenkyu) which is a systematic process used by Japanese teachers to test the effectiveness of its teaching in order to improve learning outcomes [1]. Lesson Study includes activities to develop Lesson Plan, open class (learning activities), conduct reflection forum (post-learning discussion) and archive records of learning activities [2].

Lesson study as a way to facilitate a professional learning community in the school. There are correlation between the methods of Lesson Study and the indicators of a professional learning community in elementary and middle schools [3]

Lesson Study is a model of professional development through learning activities conducted by a group of educators (teachers / lecturers) in a collaborative and sustainable way to improve the quality of learning. Lesson Study Activities has been initiated in Indonesia since around 2004/2005 along with IMSTEP implementation (1998-2005). Furthermore, Lesson Study activities were developed in schools through SISTTEMS program (2006-2008) in three pilot target areas: 1) Sumedang District (West Java), 2) Bantul Regency (DIY), 3) Pasuruan Regency (East Java). Through the PELITA program (20092013) opened new pilot areas outside Java, namely: 1) Kalimantan 2) Sumatra, and 3) Sulawesi [4].

Lesson study is a major form of improving the quality of learning and teacher professional development chosen by Japanese teachers. According to Heibert [5], lesson study is a collaborative process for a group of teachers when identifying learning problems (including book-seeking activities and articles on topics to be learned), designing a learning scenario, teaching students according to the scenario (one teacher carry out learning while others observe), evaluate and revise learning scenarios, repeat revised learning scenarios, re-evaluate learning and share the results with other teachers.

Lesson study as one of the models of professional education through collaborative learning and sustainable learning based on the principles of kolegalitas and mutual learning to build community learning [6].

Daryanto (2012), states that lesson study is a collaborative activity with initiative implementation ideally come from principal with teacher. Who wants to do these activities is very dependent on the type of lesson study developed in schoolbased, so the people who do it are all teachers from various fields of study at the school as well as the principal. This type of lesson study is carried out with the main objective of improving the quality of the process and the learning outcomes of the students regarding all the subject areas being taught.

[7], Lesson study is not a method or strategy but lesson study activities can apply various methods / learning strategies that are appropriate to the situation, condition, and problems faced by the teacher. Lesson study as an activity program to improve teacher competence and quality of learning can be developed in school as a study for the analysis of a learning practice conducted in the form of research-based learning to find specific learning innovations. 
Based on observations of several schools in Japan [8], mentioned the characteristics of lesson study there are 4, namely:

a. A long-term shared goal. Lesson study is preceded by an agreement from teachers about shared goals that need to be improved over the long term with a broader range of goals, such as: developing students' academic abilities, developing individual students' abilities, meeting students' learning needs, and so on.

b. Learning material is important. Lesson study focuses on material or lesson material that is considered important and a weak point in student learning and very difficult to learn students.

c. Study about students carefully. The main focus of lesson study is the development and learning of students, such as matters relating to the activities, participation, and conditions of each student in following the learning process. Thus, the center of attention is no longer just focused on how teachers teach.

d. Observation of learning directly. Direct observation may be said to be the center of lesson study. To assess the learning and development activities undertaken by students is not enough to do just by looking at the Lesson Plans or just view from the video show, but also must observe the learning process directly. So the data obtained about the learning process will be much more accurate and intact, until the details.

The purpose of lesson study according to [6] is to:

1. Gain a better understanding of how students learn and teach teachers;

2. Obtain certain learning outcomes that are beneficial to other teachers in carrying out learning;

3. Improve systematic learning with collaborative inquiries;

4. Build a pedagogical knowledge in which a teacher can gain knowledge from other teachers.

Lesson study has several benefits: reducing teacher's alienation (in community) in planning, learning implementation and improvement, helping teachers to observe and critiquing their learning, deepening teachers' understanding of the subject matter, their scope and sequence, assisting teachers in improvements that focus on the whole student learning activities, enhancing collaboration among teachers in learning, improving teacher quality and learning quality which in turn leads to improved quality of graduates, giving teachers the opportunity to make meaningful educational ideas in their learning practices so that teachers can change perspectives on learning, and learn the practice of learning from the perspective of students, and facilitate teachers to consult the experts in terms of learning or difficulty of subject matter [10].

The lesson study consists of 3 main stages: 1) Planning learning with academic excavation on topics and learning tools used, hereinafter referred to Plan stage. 2) Implement learning that refers to the lesson plans and tools provided, and invites peers to observe. This activity is called stage Do. 3) Implement reflection through various opinions / responses and discussions with observers / observers. This activity is called the See stage.

The stages of the implementation of lesson study, namely:

a. Planning Stage
Teachers incorporated in lesson study collaborate to develop a Lesson Plan that reflects student centered learning. Planning begins with activities to analyze the needs (need assessment) and problems encountered in learning. Furthermore, together also find solutions to solve all problems found.

\section{b. Stage of Implementation}

At this stage, there are two main activities, namely:

1) a learning implementation activity undertaken by one of the teachers agreed upon or at their own request to practice the lesson plans that have been developed together, and

2) Observation or observation activities undertaken by other members or community of lesson study (teacher, principal, or school supervisor, or other invitees acting as observers).

\section{c. Reflection Stage}

The reflection activities were conducted in the form of a discussion followed by all the lesson study participants guided by the principal or other designated participants. Starting from the delivery of impressions of teachers who have been practicing learning, by conveying comments or general impressions as well as a special impression on the learning process undertaken. All observers respond wisely to the learning process that has been implemented (not the teacher). In suggesting, the observer must be supported by evidence obtained from the observation, not on his opinion. Based on input from this discussion can be redesigned next learning [6].

Learning community is a learning community in the school environment in which the learning process between students, teachers-students, teachers, teachers-principals, schoolcommunity. While this definition is easy to pronounce and memorize, it requires deep understanding and engagement, even requiring reform of teachers' views.

Some of the following activities are examples of problemsolving efforts in order to foster learning communities in schools, for example: 1) procurement of learning resources and learning media; 2) reduce lectures but do lessons with discussion, assign tasks and scientific activities.

According Maori, Headmaster, Hamanogo Elementary school, Chigasaki, to overcome school problems, start Learning Community. There are 3 (three) slogans applied in Hamanago Elementary School namely: 1) guarantee the right of all to learn; 2) teachers and staff support each other to develop; 3) community and parents together learn to overcome school problems.

In order to create a learning community, a cooperative approach is replaced by a collaborative approach. In a collaborative approach, learning achievement by each student is of primary concern. So the teacher must guarantee the right of every student to learn and achieve learning outcomes at almost the same level.

[2], based on the ability obtained in the learning process, students can be divided into 3 groups, namely group A students with good learning outcomes (capable, mastered), group B students with learning outcomes and group learning $C$ with less learning (unable). Thus there is a learning injustice, because teachers generally only pay attention to group A or B, while 
group $\mathrm{C}$ becomes a group of students who are less attention. They will always be left behind and eventually frustrated.

Artificial grouping of students has been done in Japan in class / school students are grouped into groups A, B, and C. But now the grouping is eliminated, as Manabu explained. Similarly Finland and France. This is because without any artificial grouping, there will be a natural grouping. Artificial grouping of students into $\mathrm{A}, \mathrm{B}$ and $\mathrm{C}$ will result in group $\mathrm{C}$ students losing their spirits.

[10] argue that collaborative strategies are designed so that none of the students can not achieve the learning objectives. Through this effort, the students' inefficiency is minimized (because it is impossible to eliminate it). Not all students are able to jump (jump) in accordance with the expectations of teachers. Class $\mathrm{C}$ students do not have to be helped by $\mathrm{A}$ students, but must be handled by the teacher themselves. So the teacher should pay attention directly to the children who are less master.

In the lessons that use group work the students should each group consist of 4 children. This is intended to occur effective communication between group members. Groups should be heterogeneous, both based on gender and ability [10].

\section{MEthodology}

The type of research used is descriptive research with the method of observation in open class activities. The data collection techniques used in this research are: 1) documentation used to obtain student activity data during learning process and video documentation and photo about planning, implementation, and reflection of lesson study program, 2) observation, conducted to see student activities during process learning in lesson study 3) communication, done during reflection.

\section{RESULTS AND DISCUSSION}

Before you begin to format your paper, first write and save the content as a separate text file. Keep your text and graphic files separate until after the text has been formatted and styled. Do not use hard tabs, and limit use of hard returns to only one return at the end of a paragraph. Do not add any kind of pagination anywhere in the paper. Do not number text headsthe template will do that for you.

Measurement of quality of biology science learning is done by using the observation sheet in which there are indicators of student learning activities. This observation sheet is filled by the observer at each learning meeting. The results of the average analysis of learning activities of students of SMP Negeri 2 class VII-I can be seen in Table I, II and III.

TABLE I. AVERAGE STUDENT LEARNING ACTIVITy (1ST MEETING)

\begin{tabular}{|l|l|c|c|c|}
\hline No & \multicolumn{1}{|c|}{ Observers } & Average & Criteria & Total score \\
\hline 1 & Marlina & 19,3 & Enough & 174 \\
\hline 2 & Jumadil & 19,7 & Enough & 158 \\
\hline 3 & M. Agus Prianto & 19,8 & Enough & 179 \\
\hline \multicolumn{2}{|r|}{ Total of Average } & 58,8 & Total Score & 511 \\
\hline
\end{tabular}

From the first table the number of student learning activities class VII-I the first meeting can be obtained average student learning activities are as follows:

$$
X=\frac{\sum X}{N}=\frac{58,8}{3}=19,6
$$

Based on the data then, it can be seen that the average acquisition of student learning activities class VII-I meeting 1 during learning using lesson study learning community amounted to 19.6. It shows that based on the category of student learning activity scores, obtained that the average learning activity of students is quite or can be quite active.

The results of the average analysis of student learning activities can be seen in Table II.

TABLE II. Average Student Learning Activity (2ND MeEting)

\begin{tabular}{|l|l|l|l|l|}
\hline No & Observers & Average & Criteria & Total score \\
\hline 1 & Marlina & 21 & Good & 144 \\
\hline 2 & Jumadil & 25,4 & Good & 105 \\
\hline 3 & M. Agus Prianto & 27 & Very Good & 254 \\
\hline 4 & $\begin{array}{l}\text { Andi Norhaedah, } \\
\text { S.Pd }\end{array}$ & 24 & Good & 244 \\
\hline \multicolumn{2}{|l|}{ Total of Average } & 97,4 & Total Score & 747 \\
\hline
\end{tabular}

From Table II the number of learning activities of students of class VII-I meeting 2 can be obtained average student learning activities are as follows:

$$
X=\frac{\sum X}{N}=\frac{97,4}{4}=24,35
$$

Based on the data then, it can be seen that the average acquisition of class VII-I learning activities of class 2 during learning using lesson study learning community amounted to 24.35. It shows that based on the category of student learning activity scores, it is found that the average learning activity of students is good.

The results of the average analysis of student learning activities can be seen in Table III.

TABLE III. AVERAGE StUdENT LEARNING ACTIVITY (3 TH MEETING)

\begin{tabular}{|c|l|c|c|c|}
\hline No & \multicolumn{1}{|c|}{ Observers } & Average & Criteria & Total score \\
\hline 1 & Marlina & 28 & Very Good & 168 \\
\hline 2 & Jumadil & 31,2 & Very Good & 281 \\
\hline 3 & M. Agus Prianto & 30 & Very Good & 300 \\
\hline \multicolumn{2}{|r|}{ Total of Average } & 89,2 & Total Score & 749 \\
\hline
\end{tabular}

From Table III the number of learning activities of students of class VII-I meeting 3 can be obtained average student learning activities are as follows:

$$
X=\frac{\sum X}{N}=\frac{89,2}{3}=29,73
$$

Based on the data then, it can be seen that the average acquisition of student learning activities class VII-I meeting 3 during learning using lesson study learning community amounted to 29.73. It shows that based on the category of student learning activity score, it is found that the average result of student learning activity is very good. 
When learning activities take place observed by the observer or observer. In this study, the observer plays a role to see the quality of biology science learning, especially on the learning activities of students about the implementation of lesson study learning community during the learning process. Observation of student activity is done by giving score between 1 to 4 on observation sheet of student activity in which there are 8 categories of observation of student activity.

Lesson study learning community on biological science subjects can be implemented well. Lesson study learning community activities include assisting teachers in learning to observe and advice, making teachers better understand the curriculum, sequence and depth of the material, helping teachers to help all students learn, understanding how students think and learn. Learning tools created by model teachers are then discussed with the team, getting advice to improve the quality of learning.

Do (implementation), in the implementation stage of lesson study conducted observation. The model teacher on learning in class VII-I is Elis Triyaningsih. Observer is conducted by members of the lesson study group, namely: Marlina Piradek, Jumadil, and Muhammad Agus Prianto. Observer observes learning activities that take place with the focus of observation, namely: readiness of students in following science lessons, student responses to problems conveyed by teachers, identify problems conveyed by teachers, conduct group investigation activities, plan works, present work, analyze problem-solving process and summarize the learning materials. The focus of observation on the lesson study is; when students start to concentrate when learning, when students stop learning (bored / saturated), what is learned from the learning, and what valuable experience gained from this learning activity.

See (reflection) which includes sharing lesson study of student learning activities, not criticizing, and suggestions submitted wisely. Discussion discusses the results of observations that have been done. Observers can provide suggestions for improvements in learning. Lesson study activities in the classroom during the learning process, observer observation records help teachers to reflection, so that the quality of learning is increasing. This is in accordance with Widhiartha's (2008) statement, observers observe learning activities conducted by focusing on student performance so that problems that occur in the class can be analyzed and found the right solution, thus the problems that occur in the classroom when learning activities can be solved together -the same and further learning activities can go well and improve the quality of learning.

From the results of observation of meeting 1 discussing the definition of environmental pollution, the causes of water pollution, the impact of water pollution, and how to cope with water pollution in class VII-I observer Marlina suggests that during the learning process, students' readiness in following each group's lessons looks good by occupying seats in accordance with their respective groups, although there are still students who are busy opening the book, the students do the pre-test quietly, and concentrate again when the model teacher performs apperception by displaying the impressions through video contamination water. Suggestion from observer Jumadil is expected that at the start of the projector's learning has been prepared from the beginning so as not to interfere during the process of teaching and learning activities. The results of the questionnaire from observers Marlina, Jumadil and Muhammad Agus Prianto students began to concentrate when the teacher opened the lesson and aired a video about water pollution, and students began not concentrating during the end of the discussion, the experience gained from this learning activity is conditioned the class by walking around the students to monitor their learning activities, the experience gained from this teaching and learning activities is to carry out the practicum well and in accordance with the procedure so that the results obtained are also maximal. Based on the results of questionnaires that have been distributed to the students at the 2nd meeting, it is learned that learning about the practice of water pollution by identifying polluted water is very interesting, so that the learning experience is acquired about the characteristics of contaminated water, the result of contaminated water, need to be improved in this lesson is must be more careful in carrying out the experiment / experiment, no fuss, and improve the cooperation of members of the group. Observation of meeting 3 on air and soil pollution understanding, air pollution and soil contamination factor, and impact of air and soil contamination in class VII-I, three observers namely Jumadil, Marlina, and Muhammad Agus Prianto stated that so far in the learning activities teaching has progressed, where the students are accustomed to the model of learning given, the readiness of students in following the learning is also very good, basically lesson study is a collaborative activity, so the teacher model can allow the completed students to be able to help their friends in other groups. One of the causes of saturated students is that students who are basically smart tend to work faster on student worksheets so that no more activities are done, then the model teacher can instruct the students to help other unfinished groups, this is called by term lesson study learning community. At the time of presenting the work the students had dared to express an opinion, when the activities concluded the material most students also participated to help the model teacher to make conclusions. The result of questionnaire from observer Marlina, Jumadil, and Muhammad Agus Prianto after learning activity at meeting 3 , there have been various improvements where students start to concentrate when teachers start lesson by giving apperception, and students start not concentrate when teachers together with students make conclusion, the experience gained from teaching and learning activities is to provide information about everyday life related to the material. Based on the results of questionnaires that have been distributed to students at meeting 3, obtained information that the study of air and soil pollution is very interesting, so that gained experience learning that is increasingly widespread knowledge of soil and air pollution, things that need to be improved in this learning is to increase insight on air and soil pollution, enhancing member cooperation. Student learning activities after applying lesson study learning community have increased. In the first meeting, the students' learning activity averaged 19.6 with the category "Enough". Furthermore, at the second meeting obtained student learning activity average of 24.35 with the category of "Good". Furthermore, at the third 
meeting obtained average student learning activities of 29.73 with the category of "Very Good".

\section{ACKNOWLEDGMENT}

In this study, the authors would like to thank the Dean of the Faculty of Education Mulawarman University has provided the opportunity to the author to carry out research with DIPA funds Mulawarman 2016. On this occasion the author would like to thank validator and observers who helped research progress.

\section{REFERENCES}

[1] J. Garfield, "Exploring the Impact of Lesson Study on Developing Effective Statistics Curriculum.” 2006.

[2] S. Masaaki, "Needs of Collaborative Learning (Perlunya Pembelajaran Kolaborotif(Makalah, Terjemahan))," SISTTEMS-JICA, 2006.

[3] T. Chichibu, T. Kihara, "How Japanesee School Build a Professional Learning Community by Lesson Study," International Journal for Lesson and Learning Studies, vol. 2, no. 1, pp. 12-25, 2013.
[4] Herliani, " Development of Curriculum Models 21st Century Literacy Skills Course (Pengembangan Model Kurikulum Mata Kuliah Berorientasi Kecakapan Abad 21)", Dr, dissertation, Sains Education Dept, Surabaya State University, Surabaya, EJ, 2016.

[5] H. Susilo, "Lesson Study Berbasis Sekolah," Malang: Bayu Media, 2009.

[6] Rusman, "Learning Models Develop Teacher Professionalism (Modelmodel Pembelajaran Mengembangkan Profesionalisme Guru), J Jakarta: Rajawali Pers, 2013.

[7] Amri, Sofan. Ahmadi, Khoiru Iif, "Proses Pembelajaran Inovatif dan Kreatif dalam Kelas,” Jakarta: Prestasi Pustakaraya, 2010.

[8] C. Lewis, R. Perry, J. Hurd, "A Deeper Look At Lesson Study," Educational Leadership, vol. 61, no. 5, pp. 18-22, 2004.

[9] Sukirman, "Improving Teacher Professionalism through Lesson Study (Peningkatan Profesionalisme Guru Melalui Lesson Study)," Presented at two day training activities for facilitators and SISTTEMS TPK team-Emergency Program, Bantul, Indonesia, 2006.

[10] S. Manabu, "Tantangan yang Harus Dihadapi Sekolah (Makalah, Terjemahan)," SISTTEMS-JICA, 2006. 